\title{
SOCIO-CULTURAL CHALLENGES OF ENGLISH TEACHING IN REMOTE AREAS OF INDONESIA
}

\author{
Dwi Poedjiastutie $^{\mathrm{a}}$, Velmi Mayaputri ${ }^{\mathrm{b}}$, Yudhi Arifanic \\ (adpoedjiastutie@yahoo.com, bvelmimayaputri@gmail.com, \\ cyudhi_arif@umg.ac.id) \\ ${ }^{a, b}$ Universitas Muhammadiyah Malang \\ Jl. Raya Tlogomas No. 246 Malang, East Java, Indonesia, 65144 \\ Universitas Muhammadiyah Gresik \\ Jl. Sumatera No. 101 GKB Gresik, East Java, Indonesia, 61121
}

\begin{abstract}
The development of English language learning in any country is interdependent with its socio-cultural experiences. Learning is determined by the social, historical, economic, political, and cultural dimensions of its context. This study aims to explore the socio-cultural challenges of teaching English in a remote area. It was conducted in Pemana Island (East Nusa Tenggara) using the ethnography exploration. Pemana is one of the Indonesian government's target locations for a teaching program to improve educational quality and overcome the problem of limited number of teachers in remote areas. This program involves bachelor degree holders of English being deployed to teach in the frontier, outlying and underdeveloped region. Several challenges of English teaching and learning emerge due to socio-cultural aspects. These include the economic situation of the society, the community beliefs about English teaching, and the ill-fitting curriculum with the social condition. The teaching implications are then discussed here.
\end{abstract}

Keywords: socio-cultures, EFL, remote areas, Indonesia, curriculum development, community beliefs and perspectives

DOI: http://dx.doi.org/10.15639/teflinjournal.v32i1/97-116

Generally, the development of English language learning in any country is interdependent with the country's socio-cultural experiences. This is in accordance with the socio-cultural theory, which states that learning does not occur in a vacuum, but is determined by the social, historical, economic, 
political and cultural dimensions of its context (Polly et al., 2018; Unesco, 1983; Vygotsky, 1978).

Kramsch (1995) defined sociocultural theories from two terms that have different senses but complementary relationships: society and culture. According to Spencer-Oatey (2008), culture is the values, beliefs, rules, and behavioral conventions in societies. Furthermore, Zegarac (2007) stated that culture is a creation which was established by the earlier generation as a means of identifying a group of people. Based on the two above definitions, culture is identified as the core aspect which drives people's behavior. In sociological terms, society refers to a group of people living in a particular area with the same culture. It consists of people and institutions existing in the environment, shared beliefs, and cultural ideas (Little, 2014). In summary, society is the actor of culture actualization, allowing people to behave based on their assumptions and beliefs, and the existing rules.

Social and cultural engagement is mediated by culturally constructed tools such as language, signs, and symbols that create unique human forms of higher-level thinking. Similarly, Kramsch (1993) defined language as a social practice which people use for communication in order to participate in society. Johnson (2009) added that human cognition develops through engagement in social activities and interaction with other people, objects, and events. Therefore, human cognitive development is inseparable from social, cultural, and historical contexts from which such development emerges.

Socio-cultural aspects are determinants in Indonesian classrooms (Islam, 2017; Reida, 2015). For example, Dardjowidjojo (2003) pointed out that the Indonesian social values and beliefs demand students to respect their teachers. Consequently, students tend to accept anything their teachers deliver in the classroom as they are considered the only ones that provide the knowledge. This kind of behavior leads to teacher-centered classrooms. Teaching English requires a thorough understanding of society's cultural aspects such as beliefs, values, and linguistic backgrounds.

Currently, the English language has gained worldwide linguistic supremacy, and educators have realized that it is no longer just a course without value but an important tool for cultural exchange, cognitive development, national welfare, and international communication. Many studies examining socio-cultural challenges in the teaching of ELT have been documented. Ullah (2017) recently investigated the socio-cultural aspect and its 
strong relationship with English teaching on 100 students of Jazan University in Arab Saudi. According to Ullah, these students claimed that English was not their culture in terms of language, habits, lifestyle, and way of communication. Therefore, communicating in English daily means that westernization occurs among societies, which obviously contradicts with the culture of the MiddleEast. Regarding Saudis' powerful feeling and their firm adherence to religious values, Ahmad (2015) found that parents and EFL students believed that mastering English is not important for their future. They generally believed that obedience or submission to Allah guarantees respect more than proficiency in English. In addition, some students considered Arabic as a divine language; therefore, more attention was paid to it than the English language. The findings also revealed the tension among Saudi scholars on the possibility of English dominating government school curricula instead of Islamic values.

In other EFL contexts, Peng and Woodrow (2010), reported that Chinese Confucian heritage with elements such as other-directed self, face concerns and a submissive way of learning is the driving force capable of shaping the Chinese students' perceptions and learning behaviors in class. Furthermore, Peng (2007) carried out a qualitative study among 118 Chinese university students and identified eight themes classified into two contexts that influenced L2 communication, that is, beliefs and the social context. The Chinese and Indonesian societies tend to be collectivistic society, and collectivistic values have some significance on the things that place importance on a harmonious relationship with other members of society (Lu \& Gilmour, 2006). Peoples of both contexts place a higher emphasis on social factors rather than individualist factors, which in turn might shape their learning beliefs and experiences.

In Indian context, Al-Farabi (2015) asserted that keeping quiet and being attentive in class have been a tradition accepted by the educational systems in EFL Bangladeshi and Indian contexts. Indian children are taught not to argue with their elders or express their own feelings for the sake of social harmony. It is also considered rude to challenge teachers with questions in and outside the classroom.

Indonesia is a country with the fourth-largest population in the world after China, India and USA, with a population of more than 250 million people. It is also known as the largest archipelago country in the world with a multicultural society. According to Azzizah (2015), Indonesia consists of 300 ethnic groups along with 726 local languages, some of which were adopted from Indian, 
100 TEFLIN Journal, Volume 32, Number 1, January 2021

Arabic, Chinese, and European especially Dutch. Bahasa Indonesia is the authorized language to unify various Indonesian local languages. Lie (2007) stated that there are four language classifications in Indonesia, namely the regional, national (Bahasa Indonesia), variants of Indonesian (a mixture of Indonesian national and regional languages), and foreign languages (English, German, Arabic, etc.). This, therefore, indicates that Indonesia consists of rich cultural heritage as well as different ethnic cultures and languages.

In relation to English teaching, the diverse sociocultural backgrounds of Indonesian people also imply various challenges. Larsson (1997) stressed that individual experiences of different places, and various life histories, tend to influence the way people analyze reality. Since language and culture are closely interconnected, the cultural aspects of society certainly influence English teaching. This study concerns the sociocultural challenges in teaching English in a remote area in Indonesia. Many who live in remote areas, called as indigenous, are likely to preserve their socio-cultural beliefs and values. Languages, habits, and other traditional knowledge accumulated over thousands of years on that society may not be easily changed. It is speculated that changing society's perspectives, in which many of the people usually are in low level of schooling and living in remoteness with minimum contact with outside world is more complicated. In other words, this type of society perceive that English teaching and learning may impinge on their local values and way of life.

The present study took place in Pemana Island in East Nusa Tenggara, one of the remote areas in Indonesia which faces a lot of challenges in the teaching of foreign languages, especially English, due to not only the huge and diverse geographical regions but also their society's beliefs and perspectives. The researcher used sociocultural theory as the framework to analyze the sociocultural challenges in the teaching of English in the island. Perez (1998) and Alfred (2003) stated that sociocultural theory seeks to understand the cultural background of learners in view of how they encode and interpret the world. According to Alfred (2003), "when people learn, they construct their own knowledge and meaning according to what they already know within the social, historical, and linguistic context of their knowledge" (p. 245). This study is important to conduct as studies of cultural challenges in remote areas in Indonesia cannot be generalized due to its context uniqueness (Bjork, 2005; Coleman, 1996; Passaung, 2003). The study also contributes to the literature of 
socio-cultural approach to ELT teaching by integrating the perspectives of three groups of participants: students, English teachers, and parents. Several studies on socio-cultural aspects suggest that the involvement of parents as a part of school community has been overlooked (e.g., Donato \& MacCormick, 1994; Kinginger \& Belz, 2005). Therefore, to investigate the socio-cultural challenges that are faced by teachers in Pemana Island East Nusa Tenggara, this study involves not only teachers and students but also parents.

\section{METHOD}

This research utilized the ethnography exploration which aims at analysing a particular socio-cultural context. Creswell (1998) defined ethnography as a detailed description of the culture sharing group or individual, which produces a holistic cultural portrait as its final product. It means that ethnography attempts to provide a detailed explanation of a cultural system or social group, which might include history, religion, politics, economy, and environment. In this approach, the role of insider researcher, who is a member, or has a priori knowledge of the organization or group in which the research is being conducted, is considered critical. In the context of the present study, one of the researchers originated from Pemana Island. Having an insider researcher made a greater ease of access to the community itself.

In a broad sense, cultural context not only refers to a nation such as Indonesia, or an ethnicity group, such as Java and aboriginal. It also refers to the cultural and smaller contexts of a region such as schools, universities, and childcare centres where specific ways of life, habits, norms, and values reflecting specific patterns are visualized. Furthermore, it highlights the importance of specific contexts as cultural entities. This study was conducted in one of the remote Indonesian areas, called Pemana Island, located in East Nusa Tenggara. Smith CDM (2015) tagged this location as a remote area used by the Indonesian government to conduct the "Sarjana mengajar di daerah terdepan, terluar dan tertinggal" (SM3T) program which aims to improve educational quality and overcome the limited number of teachers in remote areas. This program involves bachelor degree holders of English teaching in the frontier, outlying, and underdeveloped regions.

Pemana island is located in Flores, East Nusa Tenggara, 19 miles from the capital city of Maumere, with a total population of 3,995 people: 2,015 males 
and 1,980 females. The people of Pemana Island originated from Celebes and migrated to East Nusa Tenggara to find better life and land for living. The society of Pemana speaks their local language Buton and the national language Bahasa Indonesia. The majority of its population are fishers and farmers with boats used to access this Island. Pemana has one senior and two junior high schools, with only three English teachers of East Nusa Tenggara origin who are willing to teach in this island. This society holds strong traditions and beliefs, which are likely to have a significant impact on English teaching. For the purpose of this study, data were obtained from three groups of research participants consisting of two English teachers, seven students (above 16 years), and seven parents using the convenient sampling method. This sampling is a type of nonprobability sampling in which people are selected because they are accessible sources of data for researchers.

In order to understand the participants' daily lives and experience, observations were conducted in the participants' natural setting without influencing participants' behavior (Kawulich, 2005). As pointed out by Bricki and Green (2007), observational data is essential in overcoming the diversity between peoples' opinions and activities, in order to help uncover hidden behaviors. One of the ambiences in understanding socio-cultural components of its community is through classroom observation (Ahmad, 2015; Gandana \& Parr, 2013; Hamied, 2012; Pazyura, 2016). The video recording of the whole classroom activities was beneficial for the researcher to avoid the missing data. In an attempt to yield the reliable information about the behavior of this society, continuous observation is necessary. The observation was conducted six times and it was when the data achieved the saturation. According to Morse (2004), saturation is identified when there is no new data found in the field work.

In addition, an interview was conducted to obtain more in-depth data on experiences, feelings, concerns, and values from participants. This study utilized the semi-structured interview in order to facilitate the collection of a comprehensive description of participants' perspectives related to their belief and perception of English teaching. The interview questions were formulated in advance; however, some questions based on the participants' responses during the interview process were improvised for clarification. Since there were three groups of participants in this study, the questions of the interview differed. Furthermore, some procedures in the interview section were formulated as 
follows. First, the English teachers were interviewed to investigate the involvement of socio-cultural aspects challenging its teaching. Secondly, the students were interviewed because they were part of the classroom society, whose experiences were taken into account. Thirdly, the parents were interviewed to obtain a comprehensive description of the society's cultural interaction. With the help of the insider researcher, the interview process was conducted in both Indonesian and local language 'Buton' to get as much information from the society

Analyzing qualitative data requires understanding how to make sense of text and images so that the researcher can form answers to the research questions (Creswell, 2012). The interviews with teachers, students, and parents of Pemana were conducted using both Buton-local language, and Indonesian. The results of transcription were translated in English and then checked by The Translation and Interpreter Division of Language Centre, Universitas Muhammadiyah Malang, Indonesia.

An iterative approach was utilized in which the researcher needed to visit and revisit the entire data and connect them with the focus of the study (Srivastava \& Hopwood, 2009). Due to the complexity of the data analysis process, the researcher broke it down into several steps as follows. First, the researcher watched the video and read the notes of each observation. In this step, the researcher also eliminated unnecessary data. Next, she identified key statements in the observation to find out the emergent categories related to the research question. Then, she listened carefully to the recorded data of interview and transcribed it. After that, she coded the data from the interviews to find out the emergent themes of socio-cultural challenges in English teaching and learning, Last but not least, the emergent themes derived from both observation and interview results were compared.

\section{FINDINGS AND DISCUSSION}

\section{Findings}

\section{The Challenge of Economic Situation in Pemana Island}

Pemana is a small island located in the Alok sub-district, Sikka district, East Nusa Tenggara province, Indonesia surrounded by ocean. The majority of its inhabitants are traditional fishers, and small percentages are farmers. Due to 
the extreme weather associated with this Island, fishers hunt for only eight months in a year and, most times, spend 13 days on the sea. The fishing methods are still very traditional, with the use of trawling nets, and traditional boats with a small machine. The farmers plant rice, corn, cassava, green beans, and some vegetables. A few people work as civil servants such as teachers of elementary, junior, and senior high schools, or as administrative staff in local government offices. Based on the data by the local office, a total of 355 families are living under poverty. This economic situation is one of the obstacles preventing students from furthering their education. There is no direct contribution of English to the societies' daily life. According to these students, they need to earn money through fishing after graduating from Senior High School.

Parents also claimed that the economy negatively impacted on students' future. They said that education is expensive; therefore, they need to work very hard to earn money and support their children from primary to high school level. Some stated that their children do not need to continue the study to the university level; rather, they need to start earning money through fishing, to support the family living. They also stated that their children have been advised to learn the basic and general knowledge of becoming fishers and farmers: "I hope to send my child to study at a higher educational level, but that is not possible due to expensive tuition-fees" (M/Parents). Another parent said:

I supported my children in high school because I believe it is essential. However, in my opinion, high school is enough because when my child goes to college, the tuition is expensive, and my income as fishers is uncertain. It is dependent on weather. I hope my child immediately helps me to earn more money after graduating high school (LOA/Parents)

Moreover, English teachers seem to agree to the fact that due to the poor economy of Pemana Island, child labor has become the norm. Based on the data obtained, about 37 boys with age ranging between 10 and 15 years old had worked as traditional fishers since they only graduated from elementary school. In line with this, English teacher of Junior High School stated that:

The majority of the boys work as fishers once they complete their primary education. They are attracted by the success of their elder brothers and join them in the trade. However, the reverse is the case for young girls as they are arranged for marriage after their primary education due to poor economic conditions. (LA/Teacher). 
Poedjiastutie, Mayaputri \& Arifani, Socio-Cultural Challenges of English Teaching 105

Due to this painful situation, English teachers feel obliged to keep motivating students for the importance of English mastery. They said:

Almost all of my students were not interested to learn English. According to them, learning English was not their immediate need for their real-life, so I need to be more patient to make them understand the importance of it for their future (M/Teacher).

\section{The Challenge of Administering National Curriculum}

The development of language curriculum at the secondary level in Indonesia utilizes the top-down approach where the government, through the Ministry of Education, decides what to learn, regardless of the society's diversity. Poedjiastutie (2019) and Watanabe (2006) state that when the curriculum is designated by the authorities, there may be discrepancies between what learners need to learn in the targeted language, and what the government wants them to achieve.

English teachers in this region faced serious obstacles in implementing the student-centered approach due to the lack of teaching resources, media, exposure, and distribution of compulsory textbooks for junior and senior high schools. These forced teachers to write and read text with the exercises on the blackboard. Consequently, they initiated to add some hours in the afternoon to substitute time used for writing the materials instead of practicing. This excerpt is taken from a senior high school teacher:

I experienced a lack of learning resources and media because the school did not obtain a compulsory textbook from the government. This greatly impedes the learning process because some hours are used to write the material on the board, thereby limiting the explanation and practicing time (M/Teacher).

Also, both teachers and students need to search for relevant resources to support the learning process. For example, students need to come along with English dictionaries to help understand the meaning of some vocabulary. The following excerpt is from the teacher: "The most challenging thing I experience during my teaching practices is translating the vocabulary. The students did not have dictionary. Therefore, I teach them new words and their meaning by translating one by one of the sentences" (LA/Teacher)

It was also observed that students tended to bring their homework to the classroom because they found English subject difficult. The phenomena indicate that there was a distance between the English teaching policy (national 
demands) and the condition of remote society (societal needs). In this sense, students are expected to be able to practice both written and spoken English using the provided materials as referred in the curriculum. However, teachers' and students' needs are not considered to facilitate the teaching in specific disadvantaged areas such as Pemana Island.

\section{The Challenge of Society's Beliefs about English}

People from Celebes migrated to Pemana Island East Nusa Tenggara and still use their local language called Buton, for daily communication. English teachers, students, and parents explained that the local language was used for different reasons. However, it was observed in classroom interaction and instruction that teachers and students used Bahasa Indonesia with struggle.

Teachers claimed that the intensive use of the local language was one of the problems in teaching English. Due to the lack of exposure, students find it difficult to master English. In this regard, the students stated that: Why do I need to study languages from other countries while I easily communicate with the local dialect? (LA/Student)

Based on the interview with parents, it was found that the use of Bahasa Indonesia to communicate was considered arrogant. Even in the school environment, both teachers and students interacted in their local language. This flaunts the government rules, which stated that the Indonesian people need to utilize the national language in the school environment. The Pemana Island inhabitants firmly adhere to the value of their past traditions, which impedes English teaching. The unsupportive environment obviously impacts on student' poor English, which is also supported by parents. "At home, I use the local language more often because I am a villager" (AB/Parents)

In addition to preserving the local language, the religious beliefs among Pemana society were speculated as another obstacle. Some parents and students claimed the Arabic language is considered compulsory to learn than English. "I prefer learning Arabic to English. By understanding Arabic, I found it easy to read and understand the meaning of the Qur'an" (LA/Student)

This claim was supported by parents: "My child needs to learn and practice Arabic because it is good for their religion understanding. English is just an international language conversation" (M/Parent)

According to them, learning Arabic is needed in an attempt to read Koran more fluently and to understand the meaning of each sentence. Also, learning 
Poedjiastutie, Mayaputri \& Arifani, Socio-Cultural Challenges of English Teaching 107

Arabic helps students write more easily. Due to the religion aspect, students and parents believed that learning Arabic provides direct contribution to their life instead of English.

\section{Discussion}

Indonesia is a multicultural and multilingual country with Indonesian as a national and unifying language. However, many ethnic groups communicate in their local languages due to the limited interaction with those outside their ethnic group. This condition may inhibit the exposure of Bahasa Indonesia. Florey (2010) reported that the eastern part of Indonesia is identified as great concern due to the numerous regional languages spoken. It is difficult for educational practitioners sent out to these areas to deliver teaching materials because they need to translate the teaching materials from Indonesian into several regional languages.

Students are not strongly motivated to learn English, despite being a compulsory subject in Indonesia and a tool for economic growth and national development. It is mostly only needed by those residing and working in large cities such as Jakarta, Yogyakarta, Surabaya, Denpasar, and Medan, where there is frequent contact with visitors from overseas. Other factors that affect English language development include geographical conditions, teacher capacity, and learner cultural differences (Dardjowidjojo, 2000; Madya, 2007; Mistar, 2005). Indonesia consists of more than 17,000 islands in the archipelago, which spread across the seas by 5,110 kilometres east to west and 1,888 kilometres north to south. Many of the islands comprise of rugged mountains and dense jungles, and over the centuries, these have served to separate tribal ethnic groups. Geographical conditions such as these pose great problems for communication and transportation. In addition, people living in these areas are deprived of access to information and education due to problems associated with delivering the textbooks, curriculum guidelines, and other educational resources (Madya, 2007). Therefore, school students living and studying in remote areas may have limited access to basic facilities necessary for the development of their English, especially when compared to those living in more developed areas. This is a key point because accessibility to English books, as dictated by its affordability, number in school libraries, internet access, availability of teaching media, and resources make a difference to the outcomes of students' development (Madya, 2007). 
108 TEFLIN Journal, Volume 32, Number 1, January 2021

The geographical differences in classroom conditions and teachers' capacity also affect English effectively. In some schools in remote areas, classes often have a total of 50 students, a condition far from ideal for English teaching. This makes it difficult to use interactive teaching methods such as learner-centred activities, and pedagogical approaches that are currently recommended. Madya (2007) stated that this situation is exacerbated because young English teachers are reluctant to take up teaching appointments in remote areas. Furthermore, teachers are geographically distant from such locations and are rarely involved in professional development.

The pluralistic nature of the Indonesian society in terms of ways of thinking also contributes to the challenges for English teaching and learning (Hamied, 1996; Lauder, 2008; Mistar, 2005; Renandya, 2004). A group of students may prefer the proper learning of the Koran to foreign languages, while the reverse is the case in another group. In Indonesia, importance is placed on learning religion; therefore, children usually learn to read the Koran at the age of 5 either in a mosque, or under the guidance of a teacher in an informal setting (Lauder, 2008; Passaung, 2003). Also, some parents send their children to Islamic boarding schools to learn Arabic, for proper understanding. Learning the Koran is valued, while English is not the priority, and for many, it is considered the colonization language.

In addition to society's economic condition and beliefs, the top-down language curriculum for the secondary level was likely difficult to implement and it needs to be adjusted with the society condition. A top-down approach is the approach where the government through the Ministry of Education decides what students, regardless of their diversity of needs, must learn and acquire. The application of this approach comes along with several consequences. Poedjiastutie (2019) argued that the freedom of schools to set up their English curriculum to match with the students' needs cannot be achieved. A number of scholars support this opinion, saying that the key programs of the educational system are in its curricula (Long, 2005; McCawley, 2009; Renold et al., 2016).

The Indonesian Government had actually tried bottom-up curriculum approach twice in Competence Based Curriculum (2004) and School Based Curriculum (2006). However, the fundamental principles of the curriculums are in stark contrast with the principles underlying the national exam. This exam should have been discontinued in the bottom-up curriculum. Otherwise, it drew teachers to adopt the traditional way of teaching English which focused on 
teaching for test purposes. As a part of innovation, curriculum development must continuously evolve to meet the challenges of the fast-changing and unpredictable globalized world. However, the changes do not always produce the desired result. Thus, the curriculum development approaches should provide teachers or educators a room for flexibility to adapt the English teaching according to the society's situations and needs.

This study also reveals that the economic situation of the family negatively impacted on students' future. Parents said that due to great expense for school, they needed to work hard to support their children from primary to high school level and it is even harder if the young Pemana should go to university. Studies claim that schooling is a large-scale social change where social activities and interaction with other people, objects and events are pivotal in shaping cognitive development (Gay \& Cole, 1967; Stevenson et al., 1978). Studies also elucidate that schooling as a social institution provides the essential needs of the society and to ensure they thrive and survive. According to Cornali (2012), it is widely believed that every country's social and economic well-being is dependent on the quality of their citizens' education. Zhao (2012) delivers a strong message that society's unwillingness to accept changes is one of the main reasons for failure. This inability also makes them look for short-term outcomes and seek immediate luxury. Zhao further stated that education is cultivated by society; therefore, the national educational system relies on the dedication and responsibility of everyone for effective functioning. A strong community backing is a crucial element for favorable gain. Hence, the society involvement for the change is recommended. The government policy which enforces society to go to send their kids to college show that we really prioritize education, but the government should pay attention to the financing system particularly for the disadvantaged areas like Pemana.

\section{The Teaching Implication}

Throughout Indonesia the need for English learning has increased over time; however, the impetus for developing English language proficiency differs across various regions of the nation. For instance, in remote and rural areas, the need for English might be viewed as less immediate. The issue that remains, however, is in determining what types of English competence students need to possess. A learner may not have a single need and the type of competence 
might vary from context to context and situation to situation. For example, the level of English language proficiency might differ for those seeking overseas scholarships, employment in a competitive commercial job market, or in a university teaching position. In an attempt to cope with the students' beliefs in the irrelevancy of the English subject, the English teachers need to be equipped and trained with the knowledge of delivering motivational values.

English teachers need to be capable of giving insight on its importance for global competition (Galloway et al., 2017). This is because ASEAN Member Countries have made significant progress in using English during its meetings. Therefore, in an attempt to be one of the competitive countries, Indonesian needs to improve its human resource. One of the most important aspects in this context is how society plays essential roles internationally. The threat of the Asian Free Trade Area (AFTA), a regional trade cooperation of ASEAN countries in the agriculture and fisheries sectors, is approaching. Children in Pemana Island, tend to continue with their parent's line of job by becoming farmers or fishers after graduating from high schools. Teachers should be capable of playing the roles as motivators, models, problem solvers and lifelong learners in the future. Competing in every AFTA sector, including fishers from other ASEAN countries, will be difficult as they need to master the English language to effectively communicate and to sell their agricultural or fishery products.

English teachers in Pemana need to be trained to create several exposures to solve the limitation of English textbooks. For example, they could integrate the use of outdoor learning activities which give opportunities for students to explore their surroundings e.g., the process of fishing and sorting the fish out. This is also one of the examples of the contribution of English towards students' real-life activities. Furthermore, the English teacher may start their classroom activities using mixed languages just to push the use of English gently. In the situation where a society learn a new language, it does not mean that they have to forget or destroy the old ones they have mastered. The two or three languages can stand side by side. Thus, this study also contributes to how language policy should be developed by basing it on the socio-cultural theory. 
Poedjiastutie, Mayaputri \& Arifani, Socio-Cultural Challenges of English Teaching 111

\section{CONCLUSIONS}

Within social context of an English classroom, EFL learners and teachers face some challenges that are impossible to resolve without the society's assistance. There is a need to evaluate beliefs, perspectives, and wants among the society which possibly hinder development. The school students' needs of having more promising future may contradict with the society's beliefs and situations. Thus, educating the society is considered as important as educating the school students for improving the current situation. More importantly, relevant policies need to be in place to support the development of educational provision in remote areas including the teaching of English.

In terms of future studies, there is a clear need to investigate the perception of the different stakeholders involved in teaching at schools in both big cities and remote areas. The results of the current investigation could be used to inform the Ministry of Education about ways to improve the English curriculum and its delivery in different areas. Similar studies of this type would also be useful to conduct. As indicated, in order to address the needs of students and parents in a remote area, not only are needs analysis study required to determine where potential problems may lie as many scholars have done, but there is also a need for current pedagogy and teaching practices to change to address the identified gaps. In this case, what type of English pedagogy and how this might be done successfully are areas worth exploring for future researchers.

\section{REFERENCES}

Ahmad, J. (2015). Traditional and socio-cultural barriers to EFL learning: A case study. English Language Teaching, 8(12), 191-208. https://doi.org/10.5539/elt.v8n12p191

Al-Farabi, R. (2015). Cultural barriers in English language learning: A sociolinguistic perspective. International Research Journal of Interdisciplinary \& Multidisciplinary Studies (IRJIMS), 1(5), 71-76. Retrieved from http://oaji.net/articles/2015/1707-1438676053.pdf

Alfred, M. V. (2003). Sociocultural contexts and learning: Anglophone Caribbean immigrant women in U.S. postsecondary education. Adult Education Quarterly, 53(4), 242-260. https://doi.org/10.1177\%2F0741713603254028 
112 TEFLIN Journal, Volume 32, Number 1, January 2021

Azzizah, Y. (2015). Socio-economic factors on Indonesia education disparity. International Education Studies, 8(12), 218-230. https://doi.org/10.5539/ies.v8n12p218

Bjork, C. (2005). Indonesian education: Teachers, schools, and central bureaucracy. Routledge.

Bricki, N., \& Green, J. (2007). A guide to using qualitative research methodology. Medecins Sans Frontieres (MSF): Field Research, 1-30. Retrieved from https://www.academia.edu/29849811/

Coleman, H. (Ed.). (1996). Society and the language classroom. Cambridge University Press.

Cornali, F. (2012). Effectiveness and efficiency of educational measures. Evaluation Practices, Indicators and Rhetoric, 2(3), 255-260. http://dx.doi.org/10.4236/sm.2012.23034

Creswell, J. W. (1998). Qualitative inquiry and research design: Choosing among five traditions. Sage.

Creswell, J. W. (2012). Educational research: Planning, conducting, and evaluating quantitative and qualitative research (4th ed.). Pearson.

Dardjowidjojo, S. (2000). English teaching in Indonesia. EA Journal, 18(1), 22-30.

Dardjowidjojo, S. (2003). The role of English in Indonesia. In K. Sukamto (Ed.), Rampai bahasa, pendidikan, dan budaya: Kumpulan esai Soenjono Dardjowidjojo [Anthology of language, education, and culture: A collection of Soenjono Dardjowidjojo's essays] (pp. 41-50). Yayasan Obor Indonesia.

Donato, R. \& MacCormick, D. (1994). A sociocultural perspective on language learning strategies: The role of mediation. The Modern Language Journal, 78(4), 453-464. https://doi.org/10.2307/328584

Florey, M. J. (Ed.). (2010). Endangered languages of Austronesia. Oxford University Press.

Galloway, N., Kriukow, J., \& Numajiri, T. (2017). Internationalisation, higher education and the growing demand for English: An investigation into the English medium of instruction (EMI) movement in China and Japan. British Council.

Gandana, I. \& Parr, G. (2013). Professional identity, curriculum and teaching Intercultural Communication: An Indonesian case study. Language, 
Poedjiastutie, Mayaputri \& Arifani, Socio-Cultural Challenges of English Teaching 113

Culture and Curriculum, 26(3), 229-246.

https://doi.org/10.1080/07908318.2013.833620

Gay, J., \& Cole, M. (1967). The new mathematics and an old culture. Holt, Rinehart, and Winston.

Hamied, F.A. (1996). EFL program surveys in Indonesian schools: Towards EFL curriculum implementation for tomorrow. In Jacobs, G. M. (1997), Language classroom for tomorrow. SEAMEO Regional Language Center.

Hamied, F. A. (2012). English in multicultural and multilingual Indonesian education. In A. Kirkpatrick \& R. Sussex (Eds.), English as an international language in Asia: Implications for language education (pp. 63-78). Springer.

Islam, R. (2017). Investigating factors that contribute to effective teachinglearning practices: EFL/ESL classroom context. English Language Teaching, 10(4), 15-21. http://doi.org/10.5539/elt.v10n4p15

Johnson, K. E. (2009). Second language teacher education: A sociocultural perspective. Routledge.

Kawulich, B.B. (2005). Participant observation as a data collection method. Forum: Qualitative Social Research, 6(2): Art.43. Retrieved from http://www.qualitative-research.net/index.php/fqs/article/view/466/996

Kinginger, C., \& Belz, J. A. (2005). Socio-cultural perspectives on pragmatic development in foreign language learning: Microgenetic case studies from telecollaboration and residence abroad. Intercultural Pragmatics, 2(4), 369-421. https://doi.org/10.1515/iprg.2005.2.4.369

Kramsch, C. (1993). Context and culture in language teaching. Oxford University Press.

Kramsch, C. (1995). The cultural component of language teaching. Language, Culture, and Curriculum, 8(2), 83-92. https://doi.org/10.1080/07908319509525192

Larsson, S. (1997). The meaning of life-long learning. In S. Walter (Ed.), Globalisation, adult education and training: Impacts and issues (pp. 250-261). Zed Books.

Lauder, A. (2008). The status and function of English in Indonesia: A review of key factors. Makara, Sosial Humaniora, 12(1), 9-20. Retrieved from http://repository.ui.ac.id/contents/koleksi/2/21ff5564b83214c97aa449dd01 55b09d142cf454.pdf 
114 TEFLIN Journal, Volume 32, Number 1, January 2021

Lie, A. (2007). Education policy and EFL curriculum in Indonesia: Between the commitment to competence and the quest for higher test scores. TEFLIN Journal, 18(1), 1-14. http://dx.doi.org/10.15639/teflinjournal.v18i1/1-15

Little, W. (2014). Introduction to Sociology - 1st Canadian edition. Retrieved from https://my.uopeople.edu/pluginfile.php/57436/mod_book/chapter/ 37634/SOC1502.Textbook.pdf

Long, M. H. (2005). Second language needs analysis. Cambridge University Press.

Lu, L., \& Gilmour, R. (2006). Individual-oriented and socially oriented cultural conceptions of subjective well-being: Conceptual analysis and scale development. Asian Journal of Social Psychology, 9(1), 36-49. https://psycnet.apa.org/doi/10.1111/j.1467-839X.2006.00183.x

Madya, S. (2007). Searching for an appropriate EFL curriculum design for the Indonesian pluralistic society. TEFLIN Journal, 18(2), 196-221. http://dx.doi.org/10.15639/teflinjournal.v18i2/196-221

McCawley, P. F. (2009). Methods for conducting an educational needs assessment: Guidelines for cooperative extension system professionals. University of Idaho.

Mistar, J. (2005). Teaching English as a foreign language (TEFL) in Indonesia. In G. Braine (Ed.), Teaching English to the world: History, curriculum and practice (pp. 75-85). Taylor and Francis.

Morse, J. M. (2004). Theoretical saturation. In M. S. Lewis-Beck, A. Bryman, \& T. F. Liao (Eds.). The Sage encyclopedia of social science research methods (p. 1123). Thousand Oaks, CA: Sage. Retrieved from http://sk.sagepub.com/reference/download/socialscience/n1011.pdf

Passaung, N. (2003). Teaching English in an 'acquisition-poor environment': An ethnographic example of a remote Indonesian EFL classroom. (Unpublished thesis, University of Sydney, Sydney, Australia).

Pazyura, N. (2016). Influence of sociocultural context on language learning in foreign countries. Comparative Professional Pedagogy, 6(2), 14-19.

Peng, J. (2007). Willingness to communicate in the Chinese EFL classroom: A cultural perspective. In J. Liu (Ed.), English language teaching in China: New approaches, perspectives, and standards (pp. 250-269). Continuum. 
Poedjiastutie, Mayaputri \& Arifani, Socio-Cultural Challenges of English Teaching 115

Peng, J.-E., \& Woodrow, L. (2010). Willingness to communicate in English: A model in the Chinese EFL classroom context. Language Learning, 60(4), 834-876. https://doi.org/10.1111/j.1467-9922.2010.00576.x

Perez, B. (1998). Sociocultural contexts of language and literacy. Lawrence Erlbaum.

Poedjiastutie, D. (2019). A complex process of autonomy curriculum approach in Indonesia. The Journal of Asia TEFL, 16(3), 1051-1058. http://dx.doi.org/10.18823/asiatefl.2019.16.3.22.1051

Reida, E. (2015). Techniques developing intercultural communicative competences in English language lessons. Procedia - Social and Behavioral Sciences, 186, 939-943. https://doi.org/10.1016/j.sbspro.2015.04.011

Renandya, W. A. (2004). Indonesia. In W. K. Ho \& R. Y. L. Wong (Eds.), Language policies and language education: The impact in East Asian countries in the next decade (2 $2^{\text {nd }} e d$.) (pp. 115-138). Times Academic Press.

Renold, U., Bolli, T., Caves, T., Bürgi, J., Egg, M. E., Kemper, J., \& Rageth, R. (2016). Feasibility study for a curriculum comparison in vocational education and training intermediary report II: Education-employment linkage index. KOF Swiss Economic Institute.

Smith, CDM. (2015). Program management consultant: Sikka district readiness assessment for participation in MCA-Indonesia's green prosperity project. CDM International Inc. (CDM Smith) and Hatfield Consultants Partnership.

Spencer-Oatey, H. (2008). Culturally speaking: Culture, communication and politeness theory ( $2^{\text {nd }}$ ed.). Continuum.

Srivastava, P. \& Hopwood, N. (2009). A practical iterative framework for qualitative data analysis. International Journal of Qualitative Methods, 8(1), 76-84. https://doi.org/10.1177\%2F160940690900800107

Stevenson, H.W., Parker, T., Wilkinson, A., Bonnevaux, B., \& Gonzalez, M. (1978). Schooling, environment, and cognitive development: A crosscultural study. Monographs of the Society for Research in Child Development, 43(3), 1-92. https://psycnet.apa.org/doi/10.2307/1166040

Ullah, F. (2017). Socio-cultural constraints in learning English language at Jazan University, Kingdom of Saudi Arabia. International Journal of 
116 TEFLIN Journal, Volume 32, Number 1, January 2021

Language and Linguistics, 5(2), 29-33.

https://doi.org/10.11648/j.ijl1.20170502.11

Unesco. (1983). Problems of culture and cultural values in the contemporary world. Unesco. Retrieved from https://unesdoc.unesco.org/ark:/48223/pf0000054681

Vygotsky, L.S. (1978). Mind in society: The development of higher psychological processes. Harvard University Press.

Watanabe, Y. (2006). A needs analysis for a Japanese high schools EFL general education curriculum. Second Language Studies, 25(1), 83-163. Retrieved from https://www.hawaii.edu/sls/wpcontent/uploads/2014/09/Watanabe.pdf

Zegarac, V. (2007). A cognitive pragmatic perspective on communication and culture. In H. Kutthoff \& H. Spencer-Oatey (Eds.). Handbook of intercultural communication (pp. 31-53). Mouton de Gruiter.

Zhao, Y. (2012). World class learners: Educating creative and entrepreneurial students. Corwin. 